\title{
Schistosoma mansoni Infection Prevalence and Associated Determinant Factors among School Children in Mana District, Jimma Zone, Oromia Region, South West Ethiopia
}

\section{Mitiku Bajiro ${ }^{1^{*}}$ and Solomon Tesfaye ${ }^{2}$}

${ }^{1}$ Jimma University Institute of Health, Faculty of Health Sciences, School of Medical Laboratory Science, Ethiopia

2Jimma University Institute of Health, Faculty of Medical Sciences, School of Medicine, Department of Biomedical Science, Anatomy Course Unit, Ethiopia

*Corresponding author: Mitiku Bajiro, Jimma University Institute of Health, Faculty of Health Sciences, School of Medical Laboratory Science, Ethiopia, Tel: +251-917-80-95-66; E-mail: mitikubajiro2008@yahoo.com

Received date: October 06, 2017; Accepted date: November 06, 2017; Published date: November 13, 2017

Copyright: @2017 Bajiro M, et al. This is an open-access article distributed under the terms of the creative commons attribution license, which permits unrestricted use, distribution, and reproduction in any medium, provided the original author and source are credited.

\begin{abstract}
Background: Human Schistosomiasis caused by S. mansoni is among the chronic neglected tropical parasitic disease. Water bodies harboring intermediate host and infested with infective Cercaria is risk factor for getting infection and contact with it for different domestic purposes. Objective: The aim of this study was to determine $S$. mansoni infections prevalence and associated determinant factors among School Children in Manna District, Southwest, Ethiopia.
\end{abstract}

Method: A cross sectional study was conducted among the school children aged between 6-19 years from March to May 2015. For diagnosis of S. mansoni, stool sample was obtained from each child and processed using Kato Katz and examined using light microscope. A questionnaire was used to collect Socio-demographic information of the school children participated and risk factors for S. mansoni infections in the study area. Data were analyzed using SPSS version 20.0 .

Results: The prevalence of S. mansoni was found to be $27.6 \%$, which was $28.6 \%$ and $26.7 \%$ among male and female, respectively. Majority of infection intensity was low with maximum 1968EPG. Bathing in river/ponds $(A O R=0.088,95 \% \mathrm{Cl}, 0.002-0.099, P=0.039)$, washing clothes in open water sources $(A O R=0.075,95 \% \mathrm{Cl}$, $0.006-0.101, P=0.002)$ and crossing rivers on bare foots (AOR=0.058, 95\% Cl, 0.05-0.087, $\mathrm{P}=0.002$ ) were independent predictors for $S$. mansoni infection ( $P$-value $<0.05)$.

Conclusion: The school children in the study area were at moderate risk of the morbidity caused by S.mansoni (prevalence $>10 \%$ and $<50 \%$ according to WHO threshold); hence a biannual MDA with PZQ is required and bathing in open water sources, washing clothes in rivers/ponds and crossing river on bare foot were independent predictors of S.mansoni infections.

Keywords: Schistoma mansoni; Prevalence; Kato-katz; Risk factors; Manna district; Jimma zone; Southwest ethiopia

\section{Introduction}

Human schistosomiasis is one of the most common neglected tropical parasitic diseases and an intravascular parasite caused by the trematode blood fluke; Schistosoma. Five species are responsible for causing human infection but $S$. haematobium, $S$. mansoni, and $S$. japonicum are among the commonest species causing human infections. It is endemic in 77 countries in tropical and subtropical regions; with an estimated number of infected individuals worldwide are 237 million and with estimates of about $600-779$ million are at risk of infection [1-3]. Schistosomiasis ranks second among parasitic diseases of socio-economic and public health importance globally and it is prevalent in 48 countries of African continent [4].

Over $90 \%$ of the disease burden is found in sub-Saharan Africa countries [5], with the predominating species; $S$. mansoni and $S$. haematobium are the main causative of schistosomiasis in Africa with an estimated number of individuals infected were 54 and 112 million respectively, and the segment of population at risk of infection for $S$. mansoni and S. haematobium were 393 and 436 million [6].

Schistosomiasis caused by $S$. mansoni is reported in Ethiopia, with various prevalence in different localities of the country as high as $90 \%$ among school children. Previous studies showed that the prevalence of S. mansoni among school children was $89.9 \%$ in Saja town [7], $85 \%$ in Zarim, 67\% Gorgora [8], 23.9\% of Surbs city of Mekelle [9], $81.3 \%$ from Wolita [10], 74.9\% from Wondo Genet [11], 33.7\% and $15.9 \%$ from Northern Gonder [12,13], 21.2\% from Southern of Lake Lagano [14], 73.9\% from Southern Tigray [15], 20.6\% Gorgora Town [16], $37.9 \%$ from Gonder [17], 1.3\% from University Gonder Community School [18] , 0.8\% from Amibera district [19], 5.95\% among school children of different water source users in Tigray [20], 67.6\% in Finchaa valley [21], 2.1 and $24 \%$ from Jimma [22,23]. Hygiene and play habits make children especially vulnerable to infection [3].

About 779 million segment of Population are at risk of infection with Schistosomiasis of which 106 million (13.6\%) live in irrigation plot or near to large dams basins and majority of these infections were prevalent among poor populations Sub-Saharan African countries [2]. 
Page 2 of 6

It is among 13 diseases identified as Neglected Tropical Diseases by World Health Organization and prevalent in tropical and sub-tropical region, especially in poor segments of the population that had low access to safe drinking water and adequate sanitation [3,24].

School-age children who live in areas with poor sanitation are often most at risk of infection because they tend to spend time swimming or bathing in water containing infectious cercariae and in Ethiopia there were finding reported, lack of awareness water contacts habits such as swimming habit in open water sources, frequency of water contact and history of treatment, agricultural activities on bare foot and washing clothes in open water sources were associated factors for $S$. mansoni infection $[2,16,25]$

The main determinants for the distribution, transmission, and spreading of both Schistosoma species ( $S$. mansoni and $S$. haematobium) in Ethiopia include water temperature, absence or presence of snail intermediate host, population movement and water impoundment for irrigation and power [26].

The high prevalence of infection with Schistosoma is closely correlated to water bodies (pond, stream, river, and dam) infested with cercariae the infective stage and contact during crossing with bare foot, swimming, washing of clothes and utensil, playing, fishing, and irrigation activity [27].

Our study area is not yet included in the epidemiological map of $S$. mansoni in Ethiopia and there are varies report of evidence the parasite existence from the local health offices in the district, health center in the village and presence of the snail intermediate host in water bodies which is infected with the infective stage in the village (Alemu Y 2013 unpublished data). To the best of our knowledge, the epidemiology of $S$. mansoni and its risk factors have not been determined in the study area and there are different water bodies in which the community have frequent contact for domestic purpose and suspected as potential risk factors. Therefore, we determined $S$. mansoni infection prevalence and its associated determinant factors among the school children in Manna District, Jimma Zone, Southwest, Ethiopia.

\section{Study area}

The study was conducted between March and May, 2015 among students of three primary schools namely Kore konjo,Wollo sefar and Saye odo in Manna District, Jimma Zone, Oromia regional state, Southwest Ethiopia. The district is located $382 \mathrm{Km}$ away from the capital city of the country and $32 \mathrm{Km}$ away from Jimma Town in Jimma Zone. The district is located at an average altitude of about $1,450 \mathrm{~m}$ above sea level. It is generally characterized by warm climate with a mean annual maximum temperature of $25^{\circ} \mathrm{C}$ and a mean annual minimum temperature of $18^{\circ} \mathrm{C}$. The annual rainfall ranges from 1,138 to $1,690 \mathrm{~mm}$ (Report document 2013/2014 of Jimma zone administration). There are different water sources (Awetu, Urgessa) in the district in which the population frequently used for domestic purpose and which could be the potential risk factor for infection of $S$. mansoni.

\section{Study population}

Study populations were all school children enrolled in three primary schools of Manna district during study period. In each school, we stratified students according to three age groups (age 6-9 years, age 10-14 years and age $15-19$ years)

\section{Sample size}

Sample size was determined using single population proportions using $\mathrm{P}=50 \%$ : to increase the number study participants and the nonrespondent rate $25 \%$ and finally we added 20 participants as we have enough man power and the necessary materials in hands.

Based on this justification we have screened five hundred students from three primary school who have catchments to Kore Konjo health and which have close proximity to water sources in the study area.

\section{Sampling techniques}

Convenient sampling technique was used to select study participant based voluntary basis from their classes using roster.

\section{Study design}

School based cross-sectional study was employed among school children of three primary schools in the Manna District.

\section{Sample processing}

The stool samples were collected using dry, clean, and labeled plastic containers and transported to Jimma University Institute of Health, Laboratory of Medical parasitology. Kato-Katz thick smear was prepared from each stool sample for the detection and quantification of the ova of $S$. mansoni.

\section{Data processing and analysis}

Data were coded, entered and cleaned by using EPI-INFO. The processing and analysis of the data were carried out using SPSS version 20.0. The Prevalence of $S$. mansoni presented in percent. Risk factors for $S$. mansoni infection were analyzed by using binary and multiple logistic regressions to determine independent risk factors.

\section{Data quality assurance}

Refreshment training was given for data collectors and laboratory technician about Kato-katz smears by experienced personnel in the field. During data processing, the quality of data was assured by coding and double entry. From both positive and negative Kato-Katz smears, $10 \%$ were randomly selected and re-read by two independent medical laboratory experts who are blind to the primary result. Moreover, fresh working solution of malachite-green was used routinely to maintain the quality of the smear.

\section{Results}

\section{Socio-demographic characteristics of study participants}

A total of 500 students (238 males and 262 females) were involved from three primary schools selected in Manna District. The largest number of study participants, $379(75.8 \%)$ were sampled from age groups of 10-14 years.

\section{Prevalence and intensity of $\boldsymbol{S}$. mansoni infection}

The overall prevalence of $S$. mansoni among student was $27.6 \%$ (138/500). The prevalence was $28.6 \%(68 / 238)$ and $26.7 \%(70 / 262)$ among male and female, respectively. The prevalence ranges from $7.3 \%$ to $36.4 \%$ among the schools with the highest prevalence $36.4 \%(41 / 99)$ 
Citation: Bajiro M, Tesfaye S (2017) Schistosoma mansoni Infection Prevalence and Associated Determinant Factors among School Children in Mana District, Jimma Zone, Oromia Region, South West Ethiopia. J Bacteriol Parasitol 8: 329. doi:10.4172/2155-9597.1000329

Page 3 of 6

in Kore Konjo school (Table 1). Majority of the infection intensity was classified as low with maximum 1968 EPG.

\begin{tabular}{|l|l|l|l|l|}
\hline \multicolumn{2}{|l}{ Variables } & \multicolumn{2}{l|}{ S. mansoni } & Total \\
\hline \multirow{2}{*}{ Sex } & Age & Positive $(\%)$ & Negative $(\%)$ & \\
\hline \multirow{5}{*}{ Male } & $6-9$ years & $5(7.7)$ & $34(92.3)$ & $39(16.4)$ \\
\cline { 2 - 5 } & $10-14$ years & $50(29.4)$ & $113(70.6)$ & $163(68.5)$ \\
\cline { 2 - 5 } & $15-19$ years & $13(27.8)$ & $23(72.2)$ & $36(15.1)$ \\
\hline \multirow{3}{*}{ Female } & $6-9$ years & $8(13.2)$ & $30(86.8)$ & $38(14.5)$ \\
\cline { 2 - 5 } & $10-14$ years & $55(23.5)$ & $158(76.5)$ & $213(83.3)$ \\
\cline { 2 - 5 } & $15-19$ years & $7(36.4)$ & $4(63.6)$ & $11(4.2)$ \\
\hline \multirow{2}{*}{ Schools } & Kore Konjo & $39(36.4)$ & $68(63.6)$ & $107(21.4)$ \\
\cline { 2 - 5 } & SayeOdo & $70(28.8)$ & $173(71.2)$ & $243(48.6)$ \\
\hline
\end{tabular}

\begin{tabular}{|l|l|l|l|l|}
\hline & WolloSefar & $11(7.3)$ & $139(92.7)$ & $150(30.0)$ \\
\hline
\end{tabular}

Table 1: Socio-demographic characteristics of school children in three primary schools in Manna District, Jimma Zone, southwest Ethiopia, 2015.

\section{Determinants of $S$. mansoni Infection}

Out of 500 school children examined, 68/238 (28.6\%) were male and $70 / 262(26.7 \%)$ female school children were positive for $S$. mansoni. The distribution of $S$. mansoni infection among each age group showed that $16.9 \%$ of $6-9$ years, $27.9 \%$ of the $10-14$ years and $42.6 \%$ of $15-19$ years were infected. Determinant factors assessment for $S$. mansoni infection age, Swimming habits, frequency of swimming, bathing and washing clothes in open water sources and crossing rivers on bare foots were analyzed using binary logistic regression and associated with $S$.mansoni infections $(\mathrm{P}<0.05)$ and those variables with p-value $<0.025$ were carried to multiple logistic regression to see independent effect of variables Table 2.

\begin{tabular}{|c|c|c|c|c|c|c|}
\hline \multicolumn{2}{|l|}{ Variables } & \multicolumn{2}{|l|}{ S. mansoni } & \multirow[t]{2}{*}{ Total } & \multirow[t]{2}{*}{ COR } & \multirow[t]{2}{*}{ P-value } \\
\hline & & Positive (\%) & Negative (\%) & & & \\
\hline \multirow{3}{*}{ Age in year } & $6-9$ & 13 (16.9) & 64 (83.1) & $77(15.4)$ & 1 & \\
\hline & $10-14$ & $105(27.9)$ & $271(72.1)$ & $376(72.5)$ & 0.3 & 0.004 \\
\hline & $15-19$ & $20(42.6)$ & $27(57.4)$ & $47(8.4)$ & 0.236 & 0.005 \\
\hline \multirow[t]{2}{*}{ Sex } & Male & 68 (25.6) & $170(74.4)$ & $238(47.6)$ & 0.825 & 0.365 \\
\hline & Female & $70(22.5)$ & $192(77.5)$ & $262(52.4)$ & 1 & \\
\hline \multirow[t]{2}{*}{ Swimming habits } & Yes & 115 (42.6) & $155(58.4)$ & $270(54)$ & 0.054 & 0.001 \\
\hline & No & $5(2.2)$ & $225(97.8)$ & $230(46.0)$ & 1 & \\
\hline \multirow[t]{3}{*}{ Frequency of swimming } & Always & $0(0)$ & $1(100)$ & $1(0.2)$ & 0.025 & 0.001 \\
\hline & Sometimes & $115(42.6)$ & $155(58.4)$ & $270(54)$ & 0 & 1 \\
\hline & Not at all & $5(2.2)$ & $224(97.8)$ & $229(45.8)$ & 1 & \\
\hline \multirow[t]{2}{*}{ Bathing habits } & Yes & 118 (33.3) & $236(66.7)$ & $354(70.8)$ & 0.011 & 0.001 \\
\hline & No & $2(1.4)$ & 144 (98.6) & $146(29.2)$ & 1 & \\
\hline \multirow[t]{2}{*}{ Washing clothes } & Yes & $118(34.4)$ & $225(65.6)$ & 343 (68.6) & 11.17 & 0.002 \\
\hline & No & $2(1.4)$ & 155 (98.6) & $157(31.4)$ & 1 & \\
\hline \multirow[t]{2}{*}{ Crossing river on barefoot } & Yes & $117(34.3)$ & $212(65.7)$ & $329(65.8)$ & 0.095 & 0.002 \\
\hline & No & $3(1.8)$ & 168 (98.2) & $171(34.2)$ & 1 & \\
\hline
\end{tabular}

Table 2: Association between $S$. mansoni infection and pre-disposing factors among school children using binary logistic regression, Manna District, Jimma Zone, southwest Ethiopia, 2015.

In multivariate analysis, bathing habits in open water sources, washing clothes in rivers or ponds and crossing rivers on bare foots were associated with $S$. mansoni infection $(<0.05)$. School children who have bathing habits in open water sources 8.8 times $(\mathrm{AOR}=0.088$, 95\% CI, 0.002-0.099, P-value $=0.039$ ) were at high risk of being infected with $S$. mansoni than those who didn't bathing in open water sources.
School children who were washing their clothes in river or ponds 7.5 time $(\mathrm{AOR}=0.075,95 \% \mathrm{CI}, 0.006-0.101, \mathrm{P}$-value $=0.002$, $)$ at high risk of being infected with $S$.mansoni than those who didn't wash their clothes in river or ponds and school children crossing rivers on bare foot 5.8 times (AOR=0.058, 95\% CI, 0.005-0.087, p-value $=0.002$,) were at high risk of being infected with $S$. mansoni than those who didn't cross the river on bare foot (Table 3 ). 
Citation: Bajiro M, Tesfaye S (2017) Schistosoma mansoni Infection Prevalence and Associated Determinant Factors among School Children in Mana District, Jimma Zone, Oromia Region, South West Ethiopia. J Bacteriol Parasitol 8: 329. doi:10.4172/2155-9597.1000329

Page 4 of 6

\begin{tabular}{|c|c|c|c|c|c|c|}
\hline \multicolumn{2}{|l|}{ Variables } & \multicolumn{2}{|l|}{ S. mansoni } & \multirow[t]{2}{*}{ Total } & \multirow[t]{2}{*}{ AOR $(95 \% \mathrm{Cl})$} & \multirow[t]{3}{*}{ P-value } \\
\hline & & \multirow{2}{*}{$\begin{array}{l}\text { Positive (\%) } \\
13(16.9)\end{array}$} & \multirow{2}{*}{$\begin{array}{l}\text { Negative (\%) } \\
64(83.1)\end{array}$} & & & \\
\hline Age in year & $6-9$ & & & $77(15.4)$ & 1 & \\
\hline & $10-14$ & $105(27.9)$ & $271(72.1)$ & $376(72.5)$ & $0.59(0.29-0.78)$ & 0.499 \\
\hline & $15-19$ & $20(42.6)$ & $27(57.4)$ & $47(8.4)$ & $0.77(0.34-0.83)$ & 0.78 \\
\hline \multirow[t]{2}{*}{ Swimming habits } & Yes & $115(42.6)$ & $155(58.4)$ & $270(54)$ & 0 & 1 \\
\hline & No & $5(2.2)$ & $225(97.8)$ & $230(46.0)$ & 1 & \\
\hline \multirow[t]{3}{*}{ Frequency of swimming } & Always & $0(0)$ & $1(100)$ & $1(0.2)$ & 0 & 1 \\
\hline & Sometimes & 115 (42.6) & 155 (58.4) & $270(54)$ & 0 & 0.99 \\
\hline & Not at all & $5(2.2)$ & $224(97.8)$ & $229(45.8)$ & 1 & \\
\hline \multirow[t]{2}{*}{ Bathing habits } & Yes & $118(33.3)$ & $236(66.7)$ & $354(70.8)$ & $0.088(0.002-0.099)$ & 0.039 \\
\hline & No & $2(1.4)$ & $144(98.6)$ & $146(29.2)$ & 1 & \\
\hline \multirow[t]{2}{*}{ Washing clothes in rivers } & Yes & $118(34.4)$ & $225(65.6)$ & $343(68.6)$ & $0.075(0.006-0.101)$ & 0.002 \\
\hline & No & $2(1.4)$ & $155(98.6)$ & $157(31.4)$ & 1 & \\
\hline \multirow[t]{2}{*}{ Crossing river on barefoot } & Yes & $117(34.3)$ & $212(65.7)$ & $329(65.8)$ & $0.058(0.005-0.087)$ & 0.002 \\
\hline & No & $3(1.8)$ & 168 (98.2) & $171(34.2)$ & 1 & \\
\hline
\end{tabular}

Table 3: Association between $S$. mansoni infection and pre-disposing factors among school children using multiple logistic regression, Manna District, Jimma Zone, southwest Ethiopia, 2015.

\section{Discussion}

In the present study prevalence of $S$. mansoni in the study area from selected primary schools in the village was $27.6 \%$ and the majority of infection intensity was low. Bathing habits in open water sources, washing clothes in rivers or ponds and crossing rivers or ponds on bare foots were independent predictors of $S$. mansoni infection in the study area.

Our present study was lower than those research findings reported from different parts of Ethiopia such as from $89.9 \%$ from Saja towm, Northwest Ethiopia [7] , 85\% in Zarim, 67\% in Gorgora [8], 33.7\% and $37.9 \%$ from northern Gonder [13,17], 73.9\% from Southern Tigray [15] 81.3\% from Wolita [10], 74.9\% from Wondo Genet [11], 67.6\% from Fincha valley Wollega [21] and 64.3\% from Northwestern Tanzania [28]. This difference may be due to long endemicity of the parasites in the study area, sample size for the study, availability of the intermediate host in open water sources which the students have frequent contact with it ecological and climatic condition .

The prevalence rate in the present study is higher than those reported 15.9\% from Northern Gonder [12], 1.3\% from community school of University of Gonder [18], 0.8 from Amibera District [19], $20.6 \%$ from among schooled children of Gorgora [16], 23.9\% from Surbs of Mekelle city [9], 20.2\% from Raya Alamata District, Northern Ethiopia [29,30], 5.95\% among school children of different source users in Tigray [20], 21.2\% from Southern Langano [14] , 2.1\% from Jimma Zone districts surrounding Gelgel Gibe area [23] , 24\% from Jimma Zone Manna District [22]. 14.4\% from Brazil [31], 4.6\% from Jos Nigeria [32], 12.6\% from Agaie Niger state Nigeria [33], and 19.8\% from Ghana [34]. This difference may be because of ecological variation, Climatic condition of study area, sample size used, contact with open water sources which is infested with infective stage of the parasites and presence of intermediate in water bodies in the area.

The prevalence in the present study is comparable with finding reported from Western Uganda which is $27.8 \%$ [35].

In the present study age, swimming habits, frequency of swimming, bathing habits, washing clothes in open water sources and crossing rivers on bare foots were factors associated with $S$. mansoni infections in the study area on binary logistic regression $(\mathrm{P}$-value $<0.05)$ and those variables with $\mathrm{P}$-value $<0.025$ were carried to multiple logistic regression to see the independent variables for $S$. mansoni infections. Based on this, bathing habits, washing clothes in open water sources and crossing rivers on bare foots were independent predictors for $S$. mansoni infection which is similar with finding reported from Gorgora town from North Gonder [16] Saja town Northwest Ethiopia [7]

\section{Conclusion}

The students in the three primary schools of Manna District, Jimma Zone were at moderate risk of the morbidity caused by $S$. mansoni (prevalence $>10 \%$ and $<50 \%$ according to WHO threshold), and hence a biannual MDA with PZQ is required. Bathing and washing clothes in open sources and crossing river/ponds on bare foot were independent predictors for $S$. mansoni infection. .

Lists of Abbreviations FEC=Fecal Egg Count; EPG=Egg Per Gram; WHO=World Health Organization; MDA=Mass Drug Administration; SPSS=Statistical Package for Social Science 
Citation: Bajiro M, Tesfaye S (2017) Schistosoma mansoni Infection Prevalence and Associated Determinant Factors among School Children in Mana District, Jimma Zone, Oromia Region, South West Ethiopia. J Bacteriol Parasitol 8: 329. doi:10.4172/2155-9597.1000329

Page 5 of 6

\section{Ethics Approval and Consent to Participate}

\section{Ethical considerations}

Ethical approval was obtained from Institutional Review Board (IRB) of Jimma University (HRPGC 118/2015) and a support letter was also obtained from the District Health Office. Only subjects whose parents/guardians signed written informed consent where included in the study. Students excreting the egg of $S$. mansoni were treated with PZQ $40 \mathrm{mg} / \mathrm{kg}$ ( (Distocide; EIPICO Egyptian International Pharmaceuticals Industries CO.A.R.E, Cairo, Egypt, under the license of SHIN POONG PHARMA.CO., LTD. SEOUL, KOREA, B.N./Mfg/ Exp:1300371, 2013/1/2016). PZQ was administered by experienced health officer and nurses

\section{Consent for publication}

Not applicable

\section{Availability of data and material}

Not applicable

\section{Competing interests}

The authors have no competing of interests to declare

\section{Funding}

Financial support was given by research and postgraduate office of Institute of Health, Jimma university

\section{Authors' contributions}

$\mathrm{MB}$ and ST: design of the study protocol and conducted survey; $\mathrm{MB}$ and ST conducted the survey; MB, ST: manuscript writing and data analysis.

\section{Acknowledgements}

The authors are grateful to school principals, the children (study participants) their parents/guardians, research and postgraduate office of Institute of health, Jimma University.

\section{References}

1. Chitsulo L, Engels D, Montresor A, Savioli L (2000) The global status of schistosomiasis and its control. Acta Trop 77: 41-51.

2. Steinmann P, Keiser J, Bos R, Tanner M, Utzinger J (2006) Schistosomiasis and water resources development: systematic review, meta-analysis, and estimates of people at risk. Lancet Infect Dis 6: 411-425.

3. WHO (2012) Schistosomiasis.

4. WHO (1999) Report of the WHO informal consultation of schistosomiasis control.

5. WHO (2010) Working to overcome the global impact of neglected tropical diseases.

6. Van der Werf MJ, de Vlas SJ, Brooker S, Looman CW, Nagelkerke NJ, et al. (2003) Quantification of clinical morbidity associated with schistosome infection in sub-Saharan Africa. Acta Trop 86: 125-139.

7. Worku L, Damte D, Endris M, Tesfa H, Aemero M (2014) Schistosoma mansoni Infection and Associated Determinant Factors among School Children in Sanja Town, Northwest Ethiopia. J of Parasitol Res 1: 8
8. Moges T, Mesganaw F, Afework K, Gebeyaw T, Van Lieshout L, et al. (2001) Schistosomiasis mansoni in school attenders and non-attenders in North-west Ethiopia. Ethi J of Hea Devel 15: 117-123.

9. Assefa A, Dejenie T, Tomass Z (2013) Infection prevalence of Schistosoma mansoni and associated risk factors among schoolchildren in suburbs of Mekelle city, Tigray, Northern Ethiopia. Mom Ethio J of Sci 5: 174-188.

10. Alemayehu B, Tomass Z (2015) Schistosoma mansoni infection prevalence and associated risk factors among schoolchildren in Demba Girara, Damot Woide District of Wolaita Zone, Southern Ethiopia. Asian Pac J Trop Med 8: 457-463.

11. Erko B, Degarege A, Tadesse K, Mathiwos A, Legesse M (2012) Efficacy and side effects of praziquantel in the treatment of Schistosomiasis mansoni in schoolchildren in Shesha Kekele Elementary School, Wondo Genet, Southern Ethiopia. Asian Pac J Trop Biomed 2: 235-239.

12. Ayalew A, Debebe T, Worku A (2011) Prevalence and risk factors of intestinal parasites among Delgi school children, North Gonder, Ethiopia. J Parasitol Vec Biol 3: 75-80.

13. Mathewos B, Alemu A, Woldeyohannes D, Alemu A, Addis Z, et al. (2014) Current status of soil transmitted helminthes and Schistosoma mansoni infection among children in to primary school in northern Gonder, Northwest Ethipia. BMC Res Notes 7: 1-7.

14. Legesse M, Erko B (2004) Prevalence of intestinal parasites among schoolchildren in a rural area close to the southeast of Lake Langano, Ethiopia. Ethio J Healt Develop 18: 116-120.

15. Dejene T, Asmelash T, Abdelkadir M (2010) Efficacy of Praziquantel in treating Schistosoma mansoni infected school children in Tumuga and Waja, North Ethiopia. Mom Ethio J Sci 2: 3-11.

16. Essa T, Birhane Y, Endris M, Moges A, Moges F (2013) Current status of Schistosoma mansoni infections and associated risk factors among student in Gorgora town, Northwest Ethiopia. ISRN Infect Dis1: 7.

17. Alemu A, Atnafu A, Addis Z, Shiferaw Y, Teklu T, et al. (2011) Soil transmitted helminths and Schistosoma mansoni infections among school children in zarima town, northwest Ethiopia. BMC Infect Dis 11: 189.

18. Gelaw A, Anagaw B, Nigussie B, Silashi B, Yirga A, et al. (2013) Prevalence of intestinal parasite infections and risk factors among school children at University of Gonder community school, Northwest Ethiopia. BMC Public Health 13: 1-7.

19. Awoke W, Bedimo M, Tarekegn M (2013) Prevalence of schistosomiasis and associated factors among students attending at elementary schools in Amibera District, Ethiopia. Open J Prev Med 3: 199-204.

20. Dejenie T, Asmelash T (2010) Schistosomiasis Mansoni among School Children of Different Water Source Users in Tigray, Northern Ethiopia. MEJS 2: 49-60

21. Haile S, Golassa L, Mekonnen Z (2012) Prevalence of Schistosoma mansoni and effectiveness of Praziquantel in school children in Finchaa valley, Ethiopia. J Parasitol Vect Biol 4: 25-30.

22. Bajiro M, Dana D, Ayana M, Emana D, Mekonnen Z, et al. (2016) Prevalence of Schistosoma mansoni infection and the therapeutic efficacy of praziquantel among school children in Manna District, Jimma Zone, southwest Ethiopia. Parasit Vectors 9: 560.

23. Yami A, Mamo Y, Kebede S (2011) Prevalence and predictors of intestinal helminthiasis among school children in Jimma Zone. Ethiop J Health Sci 21: 167-174.

24. Hotez PJ, Molyneux DH, Fenwick A, Kumaresan J, Sachs SE, et al. (2007) Control of neglected tropical diseases. N Engl J Med 357: 1018-1027.

25. Touré S, Zhang Y, Bosque-Oliva E, Ouedraogo A, Ky C, et al. (2008) Twoyear impact of single praziquantel treatment on infection in the nationa control programme on schistosomiasis in Burkina Faso. Bull World Health Organ 86: 780-787.

26. Ali A, Erko B, Michael WT, Kloos H (2006) "Schistosomiasis," in Epidemiology and Ecology of Health and Disease in Ethiopia. Berhane Y, Mariam HD, Kloos H (edn) Shama Book, Ethiopia. 
Citation: Bajiro M, Tesfaye S (2017) Schistosoma mansoni Infection Prevalence and Associated Determinant Factors among School Children in Mana District, Jimma Zone, Oromia Region, South West Ethiopia. J Bacteriol Parasitol 8: 329. doi:10.4172/2155-9597.1000329

Page 6 of 6

27. Kabatereine NB, Brooker S, Tukahebwa EM, Kazibwe F, Onapa AW (2004) Epidemiology and geography of Schistosomo mansoni inUganda: implications for planning control. Trop Med Int Health 9: 372-380.

28. Mazigo DH, Waihenya R, Mkoji MG, Zinga M, Ambrose EE, et al. (2010) Intestinal Schistosomiasis: prevalence, knowledge, attitude and practices among school children in an endemic area of north western Tanzania. J Rur Trop Public Health 9: 53-60.

29. Dejenie T, Legese K, Tomas Z, Kiros S (2013) Index of Potential Contamination for Intestinal Schistosomiasis among School Children of Raya Alamata District, Northern Ethiopia. Mom Ethio J Sci 5: 32-48.

30. Yami A, Mamo Y, Kebede S (2011) Prevalence and predictors of intestinal helminthiasis among school children in Jimma Zone. Ethio J Health Scei 21: 167-174.

31. Barbosa CS, Favre TC, Wanderley TN, Callou AC, Pieri OS (2006) Assessment of Schistosomiasis, through school surveys, in the Forest Zone of Pernambuco, Brazil. Mem Inst Oswaldo Cruz 101: 55-62.
32. Goselle NO, Anegbe D, Imandeh GN, Dakul DA, Onwuliri ACF, et al. (2010) Schistosoma mansoni infections amongst school children in Jos, Nigeria. Sci World J 5: 1-4.

33. Banji B, Babadoko M, Mohammed G, Pauline OU, Attairu AA (2012) Survey of Schistosomiasis and other intestinal helminthiases among school-aged children in Agaie, Niger state, Nigeria. J Pharma Biomed Sci 15: 1-5.

34. Anto F, Asoala V, Adjuik M, Anyorigiya T, Oduro A, et al. (2013) Water Contact Activities and Prevalence of Schistosomiasis Infection among School-age Children in Communities along an Irrigation Scheme in Rural Northern Ghana. J Bacteriol Parasitol 4: 177.

35. John R, Ezekiel M, Philbert C, Andrew A (2008) Schistosomiasis transmission at high altitude crater lakes in Western Uganda. BMC Infect Dis 8: 110 . 